\title{
Karakteristik dan Perilaku Ibu dalam Memberikan Stimulasi Perkembangan pada Anak Usia 18-24 Bulan
}

\author{
Nur Windiya*, Lili Fajria, Meri Neherta \\ Fakultas Keperawatan Universitas Andalas \\ Limau Manis, Kec. Pauh, Kota Padang, Sumatra Barat, Indonesia 25163 \\ *correspondence email: bintangwien33@gmail.com
}

\begin{abstract}
Abstrak. Pemberian edukasi kesehatan merupakan salah satu upaya untuk promotif dan preventif kepada ibu dalam memberikan stimulasi perkembangan pada anak usia 18-24 bulan.. Penelitian ini merupakan penelitian deskriptif yang bertujuan untuk mengeksplorasi karakteristik, dan perilaku ibu dalam memberikan stimulasi perkembangan pada anak usia 18-24 bulan. Hal ini dilakukan untuk dapat merencanakan pemberian intervensi lebih lanjut pada ibu yang memiliki anak usia 18-24 bulan. Tehnik pengambilan sampel menggunakan metode probability dengan tehnik cluster sampling yang berjumlah 41 responden. Instrumen penelitian menggunakan KAP (Knowledge, Attitudes, and Practices) dengan jumlah soal 30 pertanyaan, cronbach alpha pengetahuan $(0,542-0,871)$, sikap $(0,521-0,658)$ dan tindakan $(0,452-0,713)$. Analisa data menggunakan analisis univariat. Karakteristik responden pada usia 26-35- tahun (85,4\%), pendidikan terbanyak SMA (48,8\%), ibu tidak bekerja $(82,9 \%)$, suku terbanyak adalah suku minang $(92,7 \%)$, urutan anak pertama $(75,6 \%)$ dan jumlah anak terbanyak adalah dua anak $(87,8 \%)$. Nilai mean pengetahuan 58,54, nilai sikap mean 25,24, dan tindakan dengan nilai mean 60,24. Berdasarkan kesimpulan hasil penelitian perilaku ibu terkait dengan stimulasi perkembangan pada anak usia 18-24 bulan belum adekuat sehingga dapat menyebabkan anak mengalami keterlambatan atau gangguan perkembangan.
\end{abstract}

Kata kunci: Karakteristik Ibu; Stimulasi Tumbuh Kembang; Anak 18-24 bulan

Abstract. Providing education is the effort for promotif and prevntif for mother to give growth stimulation children 18-24 month. This research is a descriptive study that aims to explore the characteristics and behavior of mother for give growth stimulation children 18-24 month. This is done to be able to plan the provision of further interventions to mother have children 18-24 month. The sampling technique used probability methods with a clustersampling technique totaling 41 respondents. The research instrument used KAP (Knowledge, Attitudes, and Practices) with a total of 32 questions, Cronbach alpha knowledge (0.5420,871), attitude (0.521-0.658), and action (0.452-0.713). Data analysis using univariate analysis. Characteristics of respondents at the age of 26-35 years (85.4\%), most education is high school (48.1\%), mother not work (82.9\%), the most ethnic is minang (92,7\%), the number of children is first (87.8) and acumulation of children is second (87.8\%). The mean value of knowledge is 58.54 , attitude is with a mean value of 25.24, and practice is with a mean value of 60.24. Based on the conclusion, the results of research on the behavior of mother to give growth stimulation of children 18-24 month is inadequate make delayed and disturbance of growth.

Keywords: Mothers characteristics; Growth Stimulation; Children 18-24 month

\section{PENDAHULUAN}

Anak usia 18-24 bulan masuk kedalam kriteria periode todler atau masa anak dini, merupakan masa keemasan "golden periode" sekaligus masa kritis "critical period" (Soetjiningnsih \& Ranuh, 2016;Kementrian Kesehatan RI, 2016). Periode "golden periode" anak adalah masa di mana otak anak mengalami perkembangan paling cepat sepanjang sejarah kehidupannya, yaitu saat mencapai usia dua tahun ukuran otak anak mencapai $75 \%$ dari otak orang dewasa, dan saat usia 5 tahun ukuran otak anak mencapai $90 \%$ otak orang dewasa (Suhartanti, Rufaida, Setyowati, \& Ariyanti, 2019).

Pada golden periode ini anak mengalami peningkatan perkembangan yang pesat (Suhartanti et al., 2019). Kualitas perkembangan anak ditentukan oleh faktor internal yaitu faktor bawaan sejak lahir dan faktor eksternal yaitu faktor sekeliling (lingkungan), faktor lingkungan mikrosistem/Ibu merupakan yang paling berpengaruh karena yang paling dekat dengan anak (Soetjiningnsih \& Ranuh, 2016). Sehingga Ibu harus memenuhi kebutuhan-kebutuhan dasar anak untuk tumbuh kembang yang optimal meliputi: kebutuhan fisik-biologis (ASUH), kebutuhan kasih sayang (ASIH), dan kebutuhan stimulasi (ASAH) (Wijaya, 2021).

Angka kejadian gangguan perkembangan ditemukan yaitu lebih dari 250 juta anak dibawah usia 5 tahun pada negara-negara berkembang memiliki risiko tidak mencapai perkembangan (kognitif, bahasa, sosio emosional, dan perkembangan-perkembangan lainnya), benua Asia merupakan benua dengan gangguan tumbuh kembang anak terbanyak (Arriagada et al, 2018; WHO \& Unicef, 2011; Alkaff \& Salamah, 2020). India, Bangladesh, dan Indonesia yang menyumbang 145 juta (66\%) dari 219 juta anak-anak mengalami gangguan tumbuh kembang (WHO \& Unicef, 2011).

Data Kemenkes RI dalam profil kesehatan Indonesia tahun 2016, mengemukakan bahwa sebanyak 
$56.4 \%$ anak yang berusia di bawah lima tahun menderita gangguan tumbuh kembang (Syahailatua \& Kartini, 2020). Indikator keberhasilan program Deteksi Dini Tumbuh Kembang balita yang ditetapkan oleh Kementrian Kesehatan RI tahun 2017 adalah 90\% dari total populasi, sementara hasil Stimulasi Deteksi Dini Tumbuh Kembang balita di Propinsi Sumatra Barat tahun 2017 adalah 53.14\% (Syofiah, Machmud, \& Yantri, 2020).

Dinas Kesehatan Kota Padang melaporkan penurunan presentase pelayanan Stimulasi Deteksi Dini Tumbuh kembang dari tahun 2019 sebanyak 85\% menjadi 50,36\% pada tahun 2020, Puskesmas Anak Air menempati presentase yang terendah yaitu $31,78 \%$ dari 23 Puskesmas yang ada di kota Padang. Berdasarkan data yang didapatkan dari Dinas Kesehatan Kota Padang \& Puskesmas Anak Air, ditemukan kejadian gangguan perkembangan yaitu pada 12 anak (Dinkes Kota Padang, 2020). Data dari Puskesmas Anak Air pada tahun 2020 dari dua kelurahan yaitu kelurahan Batipuh Panjang sebanyak 5 orang anak mengalami gangguan perkembangan (motorik kasar: 2 orang, motorik halus: 1 orang ,bicara bahasa: 1 orang, sosialisasi kemandirian:1 orang), dan kelurahan Padang Sarai sebanyak 7 orang anak mengalami gangguan perkembangan (motorik kasar 3 orang: , motorik halus: 3 orang, bicara bahasa: 1 orang.

Stimulasi (ASAH) adalah kegiatan merangsang kemampuan dasar anak umur 0-6 tahun agar anak berkembang secara optimal, setiap anak perlu mendapat stimulasi rutin sedini mungkin dan terus menerus pada setiap kesempatan (Kementrian Kesehatan RI, 2016). Otak anak yang berkembang sangat pesat mengandung sekitar 100 milyar neuron, menghasilkan bertrilyuntrilyun sambungan antar neuron yang banyaknya melebihi kebutuhan, sambungan tersebut harus diperkuat melalui berbagai rangsangan (stimulasi) (Uce, 2017). Anak yang mendapatkan stimulasi terarah dan teratur, yang dilakukan sejak dini akan lebih cepat berkembang dan memiliki $30 \%$ otak yang lebih besar dibandingkan dengan anak yang kurang atau terlambat bahkan tidak mendapatkan stimulasi (Aminah, 2019; Utaminingtyas, 2019).

Pemberian stimulasi akan efektif apabila memperhatikan kebutuhan anak sesuai tahapan perkembangannya, kelompok umur dalam memberikan stimulasi pada anak balita yaitu umur 12-15 bulan, 15-18 bulan, 18-24 bulan, 24-36 bulan, 36-48 bulan, 48-60 bulan (Soetjiningnsih \& Ranuh, 2016; Kementrian Kesehatan RI, 2016). Penelitian yang dilakukan oleh Utaminingtyas (2019) menyatakan pemberian edukasi kesehatan mengenai stimulasi berpengaruh terhadap perkembangan anak umur 12-24 bulan dengan nilai $\mathrm{p}<$ 0,05 . Sedangkan menurut penelitian Obradovíc, Yousafzai, Finch, \& Rasheed (2016) dengan responden usia anak 18 bulan, 24 bulan, dan 48 bulan didapatkan bahwa kualitas stimulasi yang paling efektif yang dilakukan oleh ibu di rumah yaitu pada anak usia 18 bulan dan usia 48 bulan. Penelitian Putri (2017) juga menyatakan terdapat pengaruh pemberian edukasi kesehatan mengenai stimulasi perkembangan anak usia $1-2$ tahun dengan nilai $\mathrm{p}<\alpha$, yaitu $0,007(<0,05)$.

Dalam memberikan pendidikan kesehatan yang dapat digunakan dalam memberikan informasi dengan metode demonstrasi, merupakan tehnik mengajar dengan memperlihatkan bagaimana cara menjalankan suatu prosedur dengan sasaran pendidikan kesehatan dapat mencoba prosedur yang telah diperlihatkan oleh penyaji (notoatmojo, 2012 dalam Nurmala, 2018).

Media edukasi dapat diberikan secara audiovisual sehingga memfasilitasi dan mengakomodasi pengetahuan serta keterampilan individu (Latif, Ahmed, Amin, Syed, \& Ahmede, 2016). Menurut Susilowati (2016) jika informasi diberikan secara audiovisual kemampuan menginggat setelah 3 jam yaitu $85 \%$ dan setelah 3 hari $65 \%$. Oleh karena itu peneliti peneliti menggunakan metode demonstrasi dengan pemutaran video.

Hasil studi pendahuluan yang dilakukan oleh peneliti dengan perawat yang bertugas di Puskesmas Anak Air Kota PAdang menyatakan bahwa sudah dilaksanakan dan diberikan edukasi tentang Deteksi Tumbuh Kembang Anak, namun belum diberikan edukasi mengenai stimulasi pada kelompok usia balita sebagai tindakan pencegahan. Wawancara yang dilakukan pada 5 ibu yang memiliki anak dengan rentang usia 18-24 bulan yang datang ke Posyandu Padang Sarai menyatakan masih belum memahami tentang perkembangan anak dan cara memberikan stimulasi kepada anaknya.

\section{METODE}

Penelitian ini merupakan penelitian kuantitatif dengan desain penelitian deskriptif menggunakan teknik pengambilan sampel cluster sampling, yaitu ibu yang memiliki anak usia 18-24 bulan. Kriteria inklusi pada penelitian ini, yaitu bersedia menjadi responden, bersedia mengikuti sesi awal sampai sesi akhir, bisa baca tulis.

Instrumen penelitian adalah lembar kuesioner KAP (Knowledge, Attitudes, and Practices) yang terdiri dari empat bagian yaitu data demografi, pengetahuan, sikap dan tindakan ibu dalam memberikan stimulasi perkembangan pada anak usia 18-24 bulan dengan cronbach alpha pengetahuan (0.760), sikap (0.752) dan tindakan (0.733). Data demografi terdiri dari umur yang dikategorikan remaja akhir (17-25 tahun), dewasa awal (26-35 tahun), dewasa akhir (36-45 tahun), pendidikan dikatagorikan SD, SMP, SMA, dan PT, Pekerjaan yaitu bekerja dan tidak bekerja, suku meliputi suku minag, dan lain-lain, jenis kelamin anak laki-lai dan perempuan, urutan anak dari kel -4, julah anak dari ke 1-4.. Pengetahuan (Knowledge) dengan jumlah pertanyaan sebanyak 10 butir dengan beberapa pilihan jawaban. 
Jawaban yang paling benar diberi skor 1 , dan jawaban salah diberi skor 0. Kuesioner sikap (Attitudes ) jumlah pertanyaan masing-masing sebanyak 10 butir dengan menggunakan skala likert dengan skoring 10-40, dan (Practices) dengan skala likert dengan pilihan jawaban ya atau tidak.. Penelitian ini dilaksanakan pada bulan Juni sampai Juli 2021. Penelitian ini telah mendapatkan surat uji etik yang dikeluarkan Komisi Etik Penelitian Kesehatan RSUP Dr. M. Djamil Padang No. 252/KEPK/2021. Penelitian diawali dengan pengisian lembar informed consent oleh responden, setelah itu mengisi data demografi dan kuesioner pengetahuan, dan tindakan tentang stimulasi perkembangan pada anak usia 18-24 bulan.

Data yang telah didapatkan di analisis menggunakan analisis univariat untuk data karakteristik umur, pendidikan, pekerjaan, suku, jenis kelamin anak, urutan anak, jumlah anak dideskripsikan dengan ukuran persen atau proporsi, sedangkan pengetahuan, sikap dan tindakan dengan nilai mean, minimum, maksimum dan standar deviasi.

\section{HASIL}

Tabel 1 didapatkan jumlah responden pada penelitian ini berjumlah 41 orang. Karakteristik responden meliputi usia, dimana hampir seluruh dari ibu berusia dewasa awal (26-35 tahun) berjumlah 31 orang $(75,6 \%)$. Pendidikan ibu yang paling banyak adalah SMA 20 orang $(48,8 \%)$ sebagian besar responden tidak bekerja berjumlah 34 orang (82.9\%). Jenis kelamin lakilaki danperempuan berimbang yaitu $21(51,2 \%)$ orang dan 20 orang $(48,8 \%)$. Hampir seluruh responden berasal dari suku minang sebanyak 38 orang $(92,7 \%)$. Urutan anak responden sebagian besar urutan pertama sebanyak 17 orang $(41,5 \%$. Jumlah anak responden paling banyak berjumlah dua orang anak sebanyak 17 orang $(41,5 \%)$

Pada tabel 2 menjelaskan bahwa nilai tertinggi pada pengetahuan adalah 80 dengan rerata pengetahuan 58,54 dan SD $(15,42)$, rerata tindakan 25,24 dan $\mathrm{SD}(4,682)$ dan tindakan nilai tertinggi 90 dengan rerata 60,24 dan SD $(16,65)$

Tabel 1. Distribusi frekuensi usia caregiver lansia, jenis kelamin,

\begin{tabular}{|c|c|c|c|}
\hline Karakteristik & $\begin{array}{l}\text { Kategori } \\
\end{array}$ & f & $\%$ \\
\hline \multirow[t]{3}{*}{ Tsia Ibu } & Remaja Akhir (17-25 tahun) & 4 & 9,8 \\
\hline & Dewasa Awal (26-35 tahun) & 31 & 75,6 \\
\hline & Dewasa Akhir (36-45 tahun) & 6 & 14,6 \\
\hline \multirow[t]{4}{*}{ endidikan } & SD & 3 & 7,3 \\
\hline & SMP & 5 & 12,2 \\
\hline & SMA/SMK & 20 & 48,8 \\
\hline & PT & 13 & 31,7 \\
\hline \multirow{2}{*}{ ekerjaan } & Bekerja & 7 & 17,1 \\
\hline & Tidak Bekerja & 34 & 82,9 \\
\hline \multirow[t]{2}{*}{ uku } & Minang & 36 & 92,7 \\
\hline & Lain-lain & 3 & 7,3 \\
\hline \multirow[t]{2}{*}{ enis Kelamin Anak } & Laki-laki & 21 & 51,2 \\
\hline & Perempuan & 20 & 48,8 \\
\hline \multirow[t]{5}{*}{ Jrutan Anak } & $\mathrm{Ke}-1$ & 17 & 41,5 \\
\hline & $\mathrm{Ke}-2$ & 14 & 34,1 \\
\hline & $\mathrm{Ke}-3$ & 5 & 12,2 \\
\hline & $\mathrm{Ke}-4$ & 5 & 12,2 \\
\hline & 1 & 11 & 26,8 \\
\hline \multirow[t]{3}{*}{ umlah Anak } & 2 & 17 & 41,5 \\
\hline & 3 & 8 & 19,5 \\
\hline & 4 & 5 & 12,2 \\
\hline
\end{tabular}

Tabel 2. Pengetahuan, sikap dan tindakan caregiver dalam pencegahan COVID-19 pada lansia dengan comorbid $(n=76)$

\begin{tabular}{lccc}
\hline \multicolumn{1}{c}{ Variabel } & Mean & SD & Min-Max \\
\hline Pengetahuan & 58,54 & 15,42 & $20-80$ \\
Sikap & 25,24 & 4,862 & $17-36$ \\
Tindakan & 60,24 & 16,65 & $20-90$ \\
\hline
\end{tabular}

\section{Pembahasan}

Hasil penelitian didapatkan bahwa usia ibu hampir sebagian besar berusia pada golongan dewasa awal (26-35 tahun) yaitu sebanyak31 orang $(75,6 \%)$. Putri (2018) menyatakan bahwa Umur sangat berkaitan dengan kedewasaan seseorang, umur semakin bertambah akan meningkatkan kebijakan kemampuan seseorang untuk mengambil keputusan, berpikir rasional, mengendalikan emosi dan bertoleransi terhadap pandangan orang lain.

Menurut Mubarak (2012) saat usia bertambah dewasa maka perubahan akan terjadi pada fisik dan psikologis, pada fisik terjadi disebabkan mematangnya fungsi dari organ akan tubuh, sedangkan pada psikologis mebuat individu memiliki pola berpikir yang lebih matang dan dewasa sehingga mudah dalam menerima dan memberikan informasi.

Pendidikan ibu berpendidikan SMA sebanyak 20 orang (48.8\%). Data penelitian ini didukung oleh penelitian (Nurul Abidah \& Novianti, 2020) sebagian besar ibu berpendidikan SMA 52,5\% sebesar dan perguruan tinggi sebesar 41,3\%. Semakin tinggi pendidikan seorang ibu, maka semakain baik ibu dalam merawat anak nya sehingga mampu memacu perkembangan anaknya lebih baik (Koutra et al., 2017).

Sebagian besar ibu tidak bekerja yaitu sebanyak 34 orang $(82,9 \%)$. Hal ini sejalan dengan penelitian (Cameron et al., 2017) bahwa seorang ibu yang tidak bekerja memiliki banyak waktu untuk berinteraksi dengan anaknya Ibu yang tidak bekerja memiliki banyak waktu untuk mengasuh anak nya sehingga lebih sedikit mengalami gangguan perkembangan, dan ibu yang bekerja yang memiliki resiko 12 kali mengalami anak dengan gangguan perkembangan dibandingkan dibuktikan dalam hasil uji statistik dengan nilai OR:12 kali (Hartati, 2018). Pada penelitian (Safinatul et al., 2017) juga didapatkan hasil ibu yang tidak bekerja sebanyak $76 \%$ memiliki anak dengan tingkat perkembangan yang sesuai, diperoleh $\mathrm{OR}=22,67$ artinya antara ibu yang bekerja berisiko 22,167 kali lebih besar memilki anak dengan tingkat perkembangan yang tidak esuai dibandingkan dengan ibu yang tidak bekerja.

Responden berdasarkan suku di dominasi oleh suku minang persentasenya sebesar $92.7 \%$. Suku dan ras sangat mempengaruhi terhadap pola pengasuhan dan perkembangan anak (Williams \& Deutsch, 2016). Bahwa orang tua mempertahankan konsep tradisional suku mereka mengenai peran orang tua, bahwa orang tua mereka berhasil mendidik mereka dengan baik, maka 
mereka menggunakan teknik yang serupa dalam mendidik anak mereka (Sofiani et.al., 2020). Suku Minangkabau merupakan suku yang menganut sistem kekerabatan matrilineal, pada sistem kekerabatan ini anak mengikuti garis keturunan ibu, sehingga pada suku Minangkabau pengasuhan di dominasi oleh ibu, ibu di suku Minang akan memberikan perhatian dan pengawasan yang penuh pada anak dengan usia yang masih kecil (Satrianingrum et al., 2021)

Jenis kelamin anak adalah seimbang laki-laki 21 orang $(51,52 \%)$ dan perempuan 20 orang 48,8\%). perempuan sebanyak 72 orang $(94,75 \%)$. Dalam dalam pengasuhan anak, baik mengasuh anak laki-laki ataupun perempuan, tidak ada perbedaan yang kentara (Rahayu \& Amanah, 2016 dalam (Satrianingrum et al., 2021) ).

Hasil penelitian yang dilakukan pada 41 responden sebagian besar anak reponden merupakan anak yang pertama sebanyak 17 orang (41.5\%). Urutan anak akan mempengaruhi bentuk perhatian keluarga atau orang tua, orang tua akan mencari tau berbagai informasi mengenai perkembangan anaknya karena merupakan pengalaman pertama mereka, dan orang tua akan menjadikan anak pertama sebagai patokan untuk perkembangan anak yang berikutnya (Scarzello et.al., 2016). Sebagian besar responden memilki jumlah anak 2 orang sebesar $41.5 \%$. Jumlah anak dalam keluarga akan mempengaruhi perhatian orang tua dalam memberikan stimulasi perkembangan pada anaknya (al-Maadadi \& Ikhlef, 2015). Sejalan dengan penelitian (Widiani et al., 2016a) bahwa jumlah anak yang dimiliki cukup tidak terlalu banyak sehingga memungkinkan ibu memberikan stimulasi perkembangan pada anak secara baik.

Berdasarkan pengolahan data kuesioner pengetahuan, didapatkan rerata pengetahuan adalah 58,54 . Nilai rerata ini menunjukkan bahwa lebih dari sebagian responden telah memiliki pengetahuan cukup tentang stimulasi perkembangan pada anak usia 18-24 bulan.. Hal tersebut dibuktikan dari analisis kuesioner yang peneliti lakukan terkait pengertian dari pemberian stimulasi perkembangan.

Hasil analisis tersebut menjelaskan bahwa pengetahuan ibu mengenai stimulasi perkembangan pada anak usia 18-24 bulan belum adekuat. Pemberian stimulasi perkembangan sangat penting dilakukan oleh ibu karena yang paling terdekat dengan anak. Pengetahuan merupakan hasil dari tahu seseorang setelah melakukan pengindraan pada objek tertentu dengan melihat, mendengar dan merasakan dengan sendiri, sebagian besar pengetahuan didapat dari melihat dan mendengar (Notoatmodjo, 2012). Faktor lain yang mempengaruhi pengetahuan sesorang yaitu dari segi umur, tingkat pendidikan, pekerjaan, pengalaman individu, dan informasi yang diterima (Nurmala, 2018).

Analisis kuesioner sikap didapatkan rerata adalah 25,24 . Nilai rerata ini menunjukkan bahwa lebih dari sebagian ibu telah memiliki sikap positif tentang pemberian stimulasi perkembangan pad aanak usia 18-
24 bulan. Hasil tersebut menjelaskan bahwa sikap ibu mengenai pemberian stimulasi perkembangan pada ank usia 18-24 bulan belum seluruhnya bersikap positif. Pada item peryataan sikap mengenai prinsip pemberian stimulasi yaitu memberikan stimulasi hanya pada anak laki-laki saja dijawab dengan nilai paling rendah oleh responden. Berdasarkan hasil wawancara bahwa responden menyatakan anak laki-laki lebih diutamakan karena akan menjadi kepala rumah tangga nantinya.

Sikap suatu reaksi atau respon yang masih tertutup dari seseorang terhadap stimulus yang diterima (Maulana, 2013). Menurut Notoatmodjo (2012) sikap terdiri dari bebrapa tingkatan, seperti menerima (receving), merespon (responding), menghargai (valuing), dan bertanggung jawab (responsible). Tahapan membentuk sikap akan mengubah sikap seseorang dari negatif menjadi positif. Peningkatan sikap ibu sesuai yang dikemukana oleh Lawrence Green (1980) dalam Adventus, I Made Merta Jaya (2019) yang menjelaskan bahwa dengan memberikan peendidikan kesehatan dapat merubah faktor predisposisi, salah satu faktor predisposisi adalah sikap seseorang.

Berdasarkan kuesioner tindakan tentang praktek pemberian stimulasi perkembangan pad aanak usia 1824 bulan, didapat nilai rerata adalah 60,24 . Nilai tersebut menggambarkan responden sudah memiliki tindakan yang negatif dalam memberikan tindakan stimulasi perkembangan pad aanak usia 18-24 bulan. Hasil analisis kuesioner didapat lebih dari sebagian responden memiliki tindakan negatif tentang pemberian stiulasi pada aspek motorik kasar seperti melatih anak melempar, menagkap, dan menendang bola. Dengan kata lain, responden belum melakukan tindakan positif memberikan seluruh aspek stimulasi perkembangan pada anak usia 18-24 bulan. Meningkatkan pengetahuan ibu tentang memberikan stimulasi perkembangan pada anak usia 18-24 bulan sangatlah penting agar tidak menyebabkan penambahan kasus, sehingga bisa memahami jika anak tidak di stimulasi dengan bermain, maka perkembangan motorik halus anak akan terhambat penelitian (Utaminingtyas, 2019).

\section{SIMPULAN}

Perilaku ibu dalam memberikan stimulasi perkembangan pada anak usia 18-24 bulan belum adekuat, sehingga dapat menyebabkan lansia mempunyai resiko terjadinya keterlambatan dan gangguan perkembagan [pada anak usia 18-24 bulan. Salah satu upaya pencegahan keterlambatan dan gangguan perkembangan anak usia 18-24 bulan yaitu dengan meningkatkan pengetahuan, sikap, dan tindakan ibu dalam memebrikan stimulasi perkembangan pada anak usia 18-24 bulan dengan memberikan pendidikan kesehatan. 
Nur Windiya, Lili Fajria dan Meri Neherta, Karakteristik dan Perilaku Ibu dalam Memberikan Stimulasi Perkembangan pada

\section{DAFTAR PUSTAKA}

Aminah, M. (2019). Baby's Corner Kamus Bayi 0- 12 Bulan. Jakarta: Pt.Luxima Metro Media.

Alkaff, F. F., \& Salamah, S. (2020). Tumbuh Kembang Anak Balita di Indonesia. Retrieved April 9, 2021, from UNAIR News website: http://news.unair.ac.id/2020/12/22/tumbuhkembang-anak-balita-di-indonesia-masih-belumoptimal-atau-salah-tolak-ukur/ d

Arriagada, A.-M., Perry, J., Rawlings, L., Trias, J., \& Zumaeta, M. (2018). Promoting Early Childhood Development through Combining Cash Transfers and Parenting Programs. Promoting Early Childhood Development through Combining Cash Transfers and Parenting Programs, (December). https://doi.org/10.1596/1813-9450-8670

Cameron, J. L., Eagleson, K. L., Fox, N. A., Hensch, T. K., \& Levitt, P. (2017). Social origins of developmental risk for mental and physical illness. Journal of Neuroscience, 37(45), 1078310791.

https://doi.org/10.1523/JNEUROSCI.182217.2017

Dinkes Kota Padang. (2020). Profil Kesehatan Kota Padang 2019. Padang.

Kementrian Kesehatan RI. (2016). Pedoman Pelaksanaan Stimulasi, Deteksi, dan Intervensi Dini Tumbuh Kembang Anak. Implementation Science, 39(1), 1-15. Retrieved from http://dx.doi.org/10.1016/j.biochi.2015.03.025\%0 Ahttp://dx.doi.org/10.1038/

Koutra, K., Roumeliotaki, T., Kyriklaki, A., Kampouri, M., Sarri, K., Vassilaki, M., ... Chatzi, L. (2017). Maternal depression and personality traits in association with child neuropsychological and behavioral development in preschool years: Mother-child cohort (Rhea Study) in Crete, Greece. Journal of Affective Disorders, 217, 8998. https://doi.org/10.1016/j.jad.2017.04.002

Latif, S., Ahmed, I., Amin, M. S., Syed, I., \& Ahmede, N. (2016). Exploring the potential impact of health promotion videos as a low cost intervention to reduce health inequalities: A pilot before and after study on Bangladeshis in Inner-city London. London Journal of Primary Care, 8(4), 66-71. https://doi.org/10.1080/17571472.2016.1208382

Nurmala, I. (2018). Promosi Kesehatan. Surabaya: Arlanga.

Satrianingrum, A. P., \& Setyawati, F. A. (2021). Perbedaan Pola Penagsuhan Orang Tua Pada Anak Usia Dini Ditinjaau dari berbagai Suku Di Indonesia: Kajia Lietratur Program Studi S2 Pendidikan Anak Usia Dini, Universitas Negeri Yogyakarta 1. 16(1), 25-34.

Scarzello, D., Arace, A., \& Prino, L. E. (2016). Parental practices of Italian mothers and fathers during early infancy: The role of knowledge about parenting and child development. Infant Behavior and Development, 44(August), 133-143. https://doi.org/10.1016/j.infbeh.2016.06.006

Soetjiningnsih, \& Ranuh, I. . G. (2016). Tumbuh Kembang Anak. Jakarta: EGC.

Suhartanti, I., Rufaida, Z., Setyowati, W., \& Ariyanti, F. W. (2019). Stimulasi Kemampuan Motorik Halus Anak Pra Sekolah. In E-Book Penerbit STIKes Majapahit

Susilowati, D. (2016). Promosi Kesehatan. Jakarta Selatan: Kementrian Kesehatan Republik Indonesia.

Syahailatua, J., \& Kartini, K. (2020). Pengetahuan ibu tentang tumbuh kembang berhubungan dengan perkembangan anak usia 1-3 tahun. Jurnal Biomedika Dan Kesehatan, 3(2), 77-83. https://doi.org/10.18051/jbiomedkes.2020.v3.7783

Syofiah, P. N., Machmud, R., \& Yantri, E. (2020). Analisis Pelaksanaan Program Stimulasi, Deteksi dan Intervensi Dini Tumbuh Kembang (SDIDTK) Balita di Puskesmas Kota Padang Tahun 2018. Jurnal Kesehatan Andalas, 8(4), 151-156. https://doi.org/10.25077/jka.v8i4.1133

Wijaya, A. M. (2021). Kebutuhan Dasar Anak untuk Tumbuh Kembang yang Optimal.

WHO, \& Unicef. (2011). Role of the Health Sector in Promoting Early Childhood Development. 